\title{
A Rare Cause of Acute Abdomen in Adults: Intestinal Malrotation
}

\author{
Erişkinde Nadir Bir Akut Karın Nedeni: Intestinal Malrotasyon \\ Mürşit Dinçer, Gamze Çıtlak*, Muzaffer Akıncı* \\ University of Health Sciences Haseki Training and Research Hospital, Clinic of Gastroenterology Surgery, Istanbul, Turkey \\ *University of Health Sciences Haseki Training and Research Hospital, Clinic of General Surgery, Istanbul, Turkey
}

\begin{abstract}
Intestinal malrotation is a congenital anomaly of the midgut. The incidence of intestinal malrotation is 1 in 500 live births. It is rarely seen in adults. Most of the symptomatic patients present with acute bowel obstruction, intestinal ischemia or chronic vague abdominal pain. We present a 49-year-old male presenting with the findings of acute intestinal obstruction
\end{abstract}

Keywords: Acute abdomen, adult, malrotation

\section{Introduction}

Intestinal malrotation is a congenital anomaly of the midgut. Malrotation is defined as nonrotation or incomplete rotation of the midgut around superior mesenteric artery. The incidence of intestinal malrotation is 1 in 500 live births (1).

Most symptomatic patients present with acute bowel obstruction, intestinal ischemia or chronic vague abdominal pain. It occurs predominantly in infants and rarely in adults $(2,3)$. However, adult-age midgut malrotation is difficult to diagnose and should be kept in mind in differential diagnosis of acute abdomen due to its nonspecific presentation.

We present a 49-year-old male presenting with the findings of acute intestinal obstruction.

\section{Case}

A Forty-nine-year-old male was presented to our emergency department with the complaints of progressive abdominal distention, multiple episodes of vomiting, severe, generalized and colicky abdominal pain for the past

\section{Öz}

Intestinal malrotasyon orta barsağın konjenital bir anomalisidir. İnsidansı 500 canlı doğumda birdir. Erişkinlerde nadir olarak rastlanır. Semptomatik hastaların çoğunda akut intestinal obstrüksiyon, iskemi veya kronik karın ağrısı görülür. Bu yazıda akut intestinal obstrüksiyon bulgularıyla gelen 49 yaşında erkek hastada saptanan malrotasyon olgusu sunuldu.

Anahtar Sözcükler: Akut karın, erişkin, malrotasyon

five days. The patient also complained of non-passage of flatus and motion for the past two days. There was no history of previous surgical intervention or any medical comorbidity.

On physical examination, his vital signs were as follows: pulse: $86 \mathrm{bpm}$, blood pressure: 135/72 mmHg, and respiratory rate: 20 per minute. The temperature was $37.4^{\circ} \mathrm{C}$. Distended abdomen and mild generalized tenderness to deep palpation were present with voluntary guarding. Bowel sounds were absent. Rectal examination was unremarkable.

The patient's laboratory tests demonstrated a hemoglobin level of $16.9 \mathrm{~g} / \mathrm{dL}$, leukocyte count of $15.850 / \mathrm{mm}^{3}$ with prominent neutrophilia, C-reactive protein value of $197.6 \mathrm{mg} / \mathrm{L}$, and urea level of $72.6 \mathrm{mg} /$ $\mathrm{dL}$. All other basic biochemical parameters were within the normal limits. Abdominal $\mathrm{X}$-rays at presentation showed distended small bowel and multiple air fluid levels suggestive of intestinal obstruction (Figure 1). This was subsequently confirmed via an abdominal ultrasound. The patient was managed with nasogastric decompression and

Address for Correspondence/Yazışma Adresi: Mürşit Dinçer

University of Health Sciences Haseki Training and Research Hospital, Clinic of Gastroenterology Surgery, İstanbul, Turkey Phone: +90 5446422820 E-mail: drmursitdincer@gmail.com 
intravenous fluid support, but there was no improvement in symptoms. Abdominal computed tomography revealed gross dilatation of the small bowel and large bowel predominantly on the left side. The caecum and ileocaecal junction were located in left iliac fossa (Figure 1, 2).

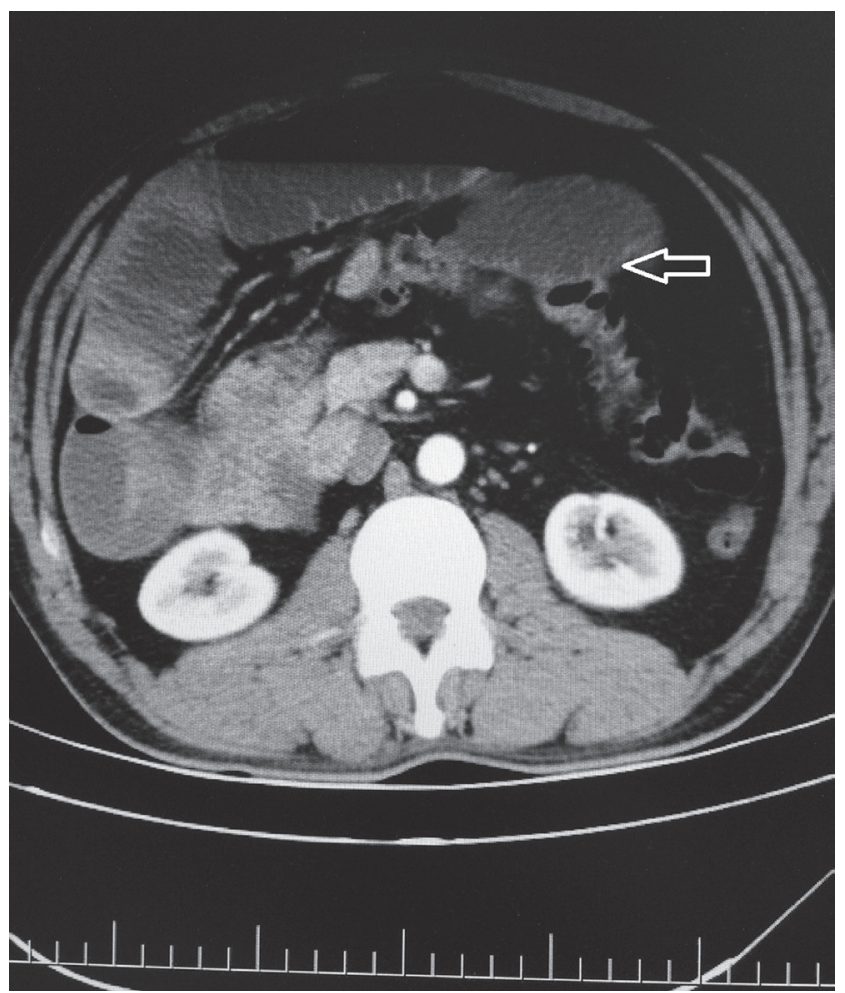

Figure 1. Computerized tomography scan of abdomen showing intestinal obstruction



Figure 2. Caecum in the left iliac fossa
The patient was planned for surgery and laparotomy was performed. Surgical findings confirmed dilatation of the small bowel and all colon segments with the caecum found on the left side of the abdomen (Figure 3). The mobile mesentery was fixed. Midgut volvulus in a clockwise direction was found. The volvulus was untwisted completely in a counter-clockwise direction and then the viability of the bowel was assessed. Segmented massive gangrene of the small bowel was present. A forty $\mathrm{cm}$ area of necrotic small intestine from $10 \mathrm{~cm}$ proximal of the terminal ileum was resected and the abdomen was then closed. The patient was discharged on the fifth postoperative day with no complication.

\section{Discussion}

Intestinal malrotation is a rare condition more rarely presenting in late adulthood. It presents usually in the neonatal period and early childhood. Seldom have been the cases of malrotation presenting in adulthood as obstruction been reported (4). The normal rotation of intestinal development has been divided into three stages. Stage one occurs between five and ten weeks of gestation. It includes extrusion of the midgut into the extraembryonic cavity, a $90^{\circ} \mathrm{C}$ counterclockwise rotation, and return of the midgut into the fetal abdomen. Stage two

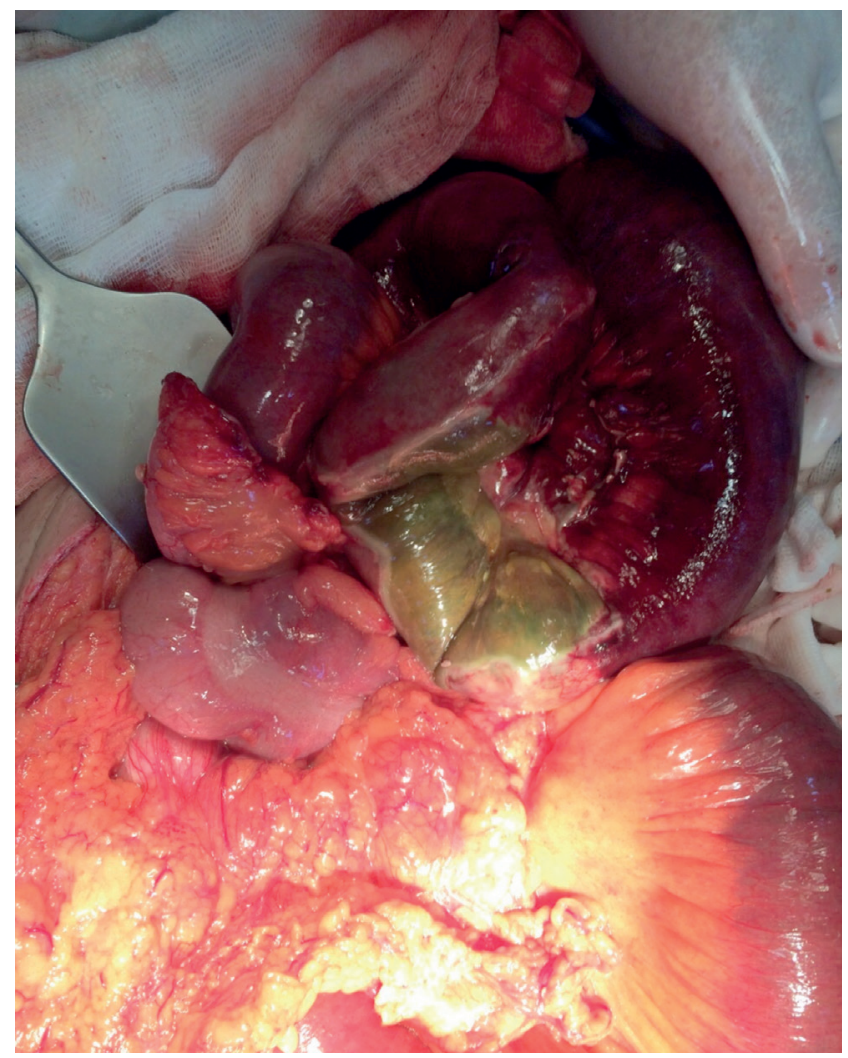

Figure 3. Intraoperative photograph of the patient with intestinal ischemia 
occurs in week 11 and involves further counter-clockwise rotation within the abdominal cavity, completing a $270^{\circ}$ rotation. This rotation brings the duodenal " $\mathrm{C}$ " loop forms behind the superior mesenteric artery with the ascending colon to the right, the transverse colon above, and descending colon to the left. Stage three involves fusion and anchoring of the mesentery. The caecum descends, and the ascending and descending colon attach to the posterior abdominal wall. According to this concept, cases of failure of rotation will involve the entire midgut, and a classical and severe malposition will result, with the small bowel located on the right side and the colon on the left side of the peritoneal cavity. Stage one anomalies include omphaloceles; Stage two anomalies involve nonrotation, malrotation, and reversed rotation. Stage three anomalies include unattached duodenum, mobile caecum, and unattached small bowel mesentery $(5,6)$.

The presentation of intestinal malrotation in adults occurs in approximately $0.2-0.5 \%$ (1). Acute presentation is with volvulus of midgut or ileocecum. The chronic presentation includes chronic abdominal pain, bloating, vomiting, constipation and diarrhea (7). Diagnosis is made in the adult in the presence of chronic abdominal symptoms during surgery for acute abdomen, or incidentally during an imaging exam for no specific symptoms. The majority of midgut malrotation in adults remains asymptomatic throughout life (8). In asymptomatic patients with intestinal malrotation, observation is enough (9). In symptomatic adults with malrotation, midgut volvulus is the most common cause of acute abdomen. The treatment of a symptomatic malrotation is primarily surgical. Emergency exploration and resection of the necrotic bowel is important for survival (7). There is no standard operation mentioned in the literature or textbooks covering the treatment of a typical malrotation (4).

As a conclusion, midgut malrotation occurs rarely in adults. Therefore, midgut malrotation in adults is difficult to diagnose and should be kept in mind in differential diagnosis of acute abdomen due to its nonspecific presentation.

\section{Ethics}

Peer-review: Internally peer-reviewed.

\section{Authorship Contributions}

Surgical and Medical Practices: M.D. Concept: G.Ç. Design: G.Ç. Data Collection or Processing: G.Ç. Analysis or Interpretation: M.A. Literature Search: M.A. Writing: M.D.

Conflict of Interest: No conflict of interest was declared by the authors.

Financial Disclosure: The authors declared that this study received no financial support.

\section{References}

1. Singh S, Das A, Chawla AS, Arya SV, Chaggar J. A rare presentation of midgut malrotation as an acute intestinal obstruction in an adult: Two case reports and literature review. Int J Surg Case Rep 2013;4:72-5.

2. Hsu SD, Yu JC, Chou SJ, Hsieh HF, Chang TH, Liu YC. Midgut volvulus in an adult with congenital malrotation. Am J Surg 2008;195:705-7.

3. Applegate $\mathrm{KE}$, Anderson JM, Klatte EC. Intestinal malrotation in children: a problem-solving approach to the upper gastrointestinal series. Radiographics 2006;26:1485-500.

4. Saxena D, Pandey A, Singh RA, et al. Malrotation of gut with superior mesentric artery syndrome and multiple jejunal diverticula presenting as acute intestinal obstruction in 6th decade: A rare case report. Int J Surg Case Rep 2015;6C:1-4.

5. Mallick IH, Iqbal R, Davies JB. Situs inversus abdominus and malrotation in an adult with Ladd's band formation leading to intestinal ischaemia. World J Gastroenterol 2006;12:40935.

6. Martin $\mathrm{V}$, Shaw-Smith C. Review of genetic factors in intestinal malrotation. Pediatr Surg Int 2010;26:769-81.

7. Sozen S, Guzel K. Intestinal malrotaiton in an adult: case report. Ulus Travma Acil Cerrahi Derg 2012;18:280-2.

8. Birnbaum DJ, Geffroy Y, Goin G, Balandraud P. Left Side Appendicitis with Midgut Malrotation in an Adult. J Surg Tech Case Rep 2013;5:38-40.

9. Vural V, Turkoglu MA, Karatas G. Incidental midgut malrotation detected during second laparotomy: Case report and literature review. Int J Surg Case Rep 2015;7C:134-6. 